\title{
Investigation of land use changes on soil erosion process using geographical information system
}

\author{
${ }^{1}$ K. Solaimani; ${ }^{1}$ S. Modallaldoust; ${ }^{2 *}$ S. Lotfi \\ ${ }^{1}$ Department of Watershed Management, University of Agriculture and Natural Resources, Sari, Iran \\ ${ }^{2}$ Department of Geography, University of Mazandaran, Babolsar, Iran \\ Received 22 August 2008; $\quad$ revised 17 March 2009; accepted 2 May 2009; $\quad$ available online 1 June 2009
}

\begin{abstract}
Land use change quantified for the last 50 years within and near a fast growing agricultural land in Neka River Basin, using geographic information systems. Land cover and land use change was projected for the next decade using topography, geology, land use maps and remote sensing data of the study area. The study explored the relationships between agricultural land growth and landscape changes. The land use changes assessed among the different land cover classes. It is important to mention that conducting of the present study a very severe land cover changes taken place as the result of agricultural land development. These changes in land cover led to the forest degradation of the study area. Relationship between land-use changes and agricultural growth offered a more robust prediction of soil erosion in Neka watershed. This study aims to find the relationships between land use pattern, erosion and the sediment yield in the study area. The land use coefficient has applied in the model of erosion potential method to forecast the effect of the land type to reduce the erosion. The results of this study indicated that the total sediment yield of the study area has notably decreased to $89.24 \%$ after an appropriate land use/cover alteration. The estimated special erosion for the southern Neka Basin is about $144465.1 \mathrm{~m}^{3} / \mathrm{km}^{2}$ where after management policy is predicted $15542.9 \mathrm{~m}^{3} / \mathrm{km}^{2} / \mathrm{y}$. Therefore, the total difference for the study area has estimated about $128922.2 \mathrm{~m}^{3} / \mathrm{km}^{2} / \mathrm{y}$.
\end{abstract}

Key words: Change detection; Erosion potential method; Land-cover; Remote sensing

\section{INTRODUCTION}

Intensive use of natural resources calls for increasingly detailed inventories of its components and an investigation of the changes which took place in the past (Aaviksoo, 1995; Simonet et al., 2003). This is particularly important in fast, usually unplanned, changing areas, such as agricultural land expansion in Northern part of Iran. At present, physical expansion of urban areas and extensive use of land for agricultural purposes are the main causes of land use change in the developing countries. Land cover change directly affects ecological landscape functions and processes with far-reaching consequences for biodiversity and natural resources (Hansen et al., 2004; Stoate et al., 2001). The potential for surface runoff and soil erosion has mostly affected by land use and cultivation (Van Rompaey et al., 2001; 2002). Erosion is one of the most significant forms of land degradation (soil truncation, loss of fertility, slope instability), greatly influenced by land use and

\footnotetext{
$\triangle$ *Corresponding Author Email: sedlotfi@yahoo.com

Tel.:+98911 212 2854; Fax: +981125280997
}

management (Bini et al., 2006; Rey, 2003). Soil forming environments and erosion processes is a muchdebated question when studying the relationship between human impact and environment change (Ballantyne and Wittingtone, 1999; Vanniere et al., 2003). Agricultural land use is one of the most important factors that have shaped historic landscapes in Europe (Bakker et al., 2005; Bickik et al., 2001; Jordan et al., 2005; Sun et al., 2003; Szilassi et al., 2006). Bodnar et al. (2006) in a study entitled ex-post evaluation of erosion control in southern Mali, compared the erosion situation in a rural area. Fanetti and Vezzoli (2007) were calculated sediment input using different magnitude equations for the Alpine watershed and the erosion potential method (EPM) in geographical information system (GIS) environment.

The erosion potential method in this study already applied on some watersheds in Iran and it is concerned that the gained results are well matched with the field investigations (Modallaldoust, 2007). An important evolution of the Gavrilovic EPM model is its 
application based on spatially distributed input data (geology, soil and land use) in a geographic information systems environment (Emmanouloudis et al., 2003; Fanetti and Vezzoli; 2007; Globevnik et al., 2003). Application of GIS technique is based on calibrated values of four basic factors which influence erosion rate: (a) climate (precipitation and temperature), (b) vegetation (type and distribution), (c) relief (difference in elevation; slope angle) and (d) soil and rocks properties (erodibility and porosity). To calibrate of these factors, it is needed to prepare some data such as field survey, map digitization, extensive data processing and model validation. The process of erosion estimation and sediment transport would be significantly simpler using aerial photographs and satellite data, digital and thematic maps. This study applied GIS as a priority technique in watershed management to identify and quantitative classification for an extensive area with a similar pattern of erosion. This would be required to produce a digital elevation model (DEM) and identifying the area with a similar conditions such as geological and vegetation characteristics. The final creation would be a multilayer map to identify area with a similar erosion patterns. The EPM gives an efficient combination of physical parameters such as geology ( $y$ coefficient), soil dynamics ( $\Psi$ coefficient) and vegetation ( $\mathrm{Xa}$ coefficient) contribution. In this study, EPM model and analytical GIS tools are used for the land management in order to erosion reduction in the study area. Land use changes related to the slop factor is capable to reduce the rate of erosion up to $89.24 \%$

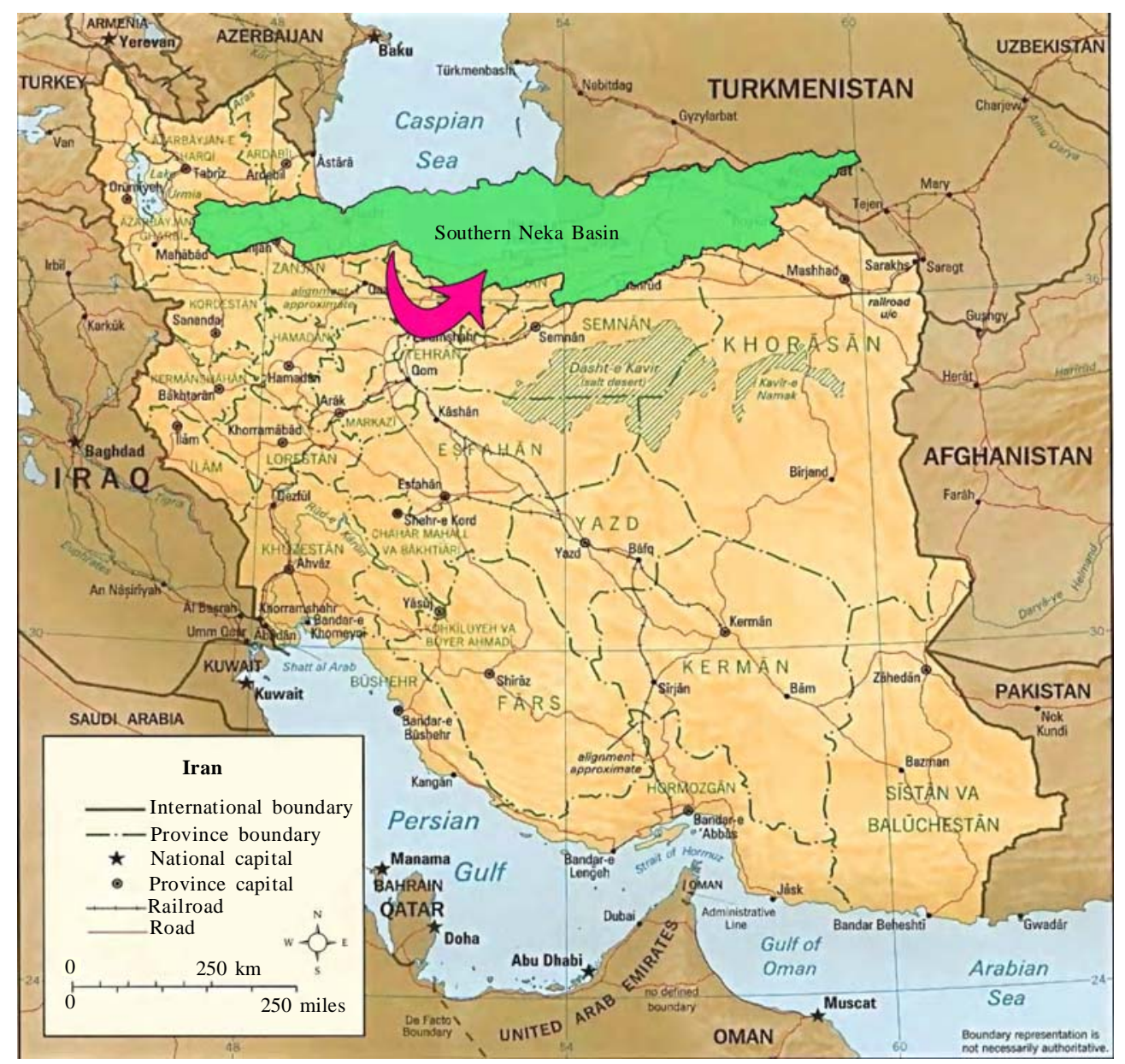

Fig. 1: Location of the study area 


\section{MATERIALS AND METHODS}

Study area

The present research was conducted in the summer of 2008. Neka River basin one of the largest watershed in Mazandaran Province is draining the northern flank of Alborz range to the Caspian Sea which divides Neka city to the eastern and western parts. The tributaries of this watershed originated from mountainous and forest upland and geologically covered by Shemshak and quaternary materials. Climate is temperate and seasonal; original land-cover was temperate hyrcanian mixed forest. Major land-uses in the area are rain-fed agriculture and cattle-grazing. The geographical location of the southern Neka Basin indicates $53^{\circ}, 07^{\prime}, 57^{\prime}$ ' E to $54^{\circ}, 09^{\prime}, 03^{\prime \prime}$ E and $36^{\circ}, 19^{\prime}, 50^{\prime \prime}$ N $\mathrm{N}$ to $36^{\circ}, 32^{\prime}, 42^{\prime \prime}$ N, based on Neka topography map published by the Iranian Geographical Organization (Fig. 1).

\section{Approach}

To quantify land cover-land-use change landcover patterns were interpreted on sequential black and white panchromatic aerial photographs (1955, 1965 and 1994), corresponding to the Southern Neka basin and the surrounding area. Aerial photography approximate scales were, respectively, 1:55,000, $1: 50,000$ and $1: 20,000$. To compare results of prediction with independent data, an enhanced and georeferenced IRS Pan and Liss of 2006, with $5.8 \mathrm{~m}$ spatial resolution was used. Accompanying cartographic data encompassed a topographic map (1:50,000 scale, $20 \mathrm{~m}$ contour interval), as well as thematic maps of geology and land-use. The used cartographic material and the aerial photographs data were produced by the Iranian Geographical Organization (IGO). All data sets were handled in digital format in GIS environment (Arc GIS9.2).

Landscape described using a terrain analysis approach where landforms and land-cover are combined (Verstappen and van Zuidam, 1991). Differentiating mapping criteria for landforms were lithology and rock structure, morphometry and soil type. Major landforms discriminated were slopes, foot-slopes, alluvial plains, valleys and isolated hills. Land-cover categories were temperate mixed forest, grasslands and croplands. Land-use was related to land-cover and function; it encompassed primary activities (forestry and agriculture). Aerial photo interpretation was carried out using standard photographic keys (tone, texture, pattern, shape and size). The minimum mapping unit was set at $30 \mathrm{~m}$ on the base map for both, radius of circular features and side of rectangular features. This size corresponded to real features on aerial photographs. Finally, ground information was collected between 2007 until 2008, as well as from Mazandaran Province natural resources office for the purpose of classification accuracy assessment. For the erosion hazard classification, the required factors such as soil type, surface geology, land use, slope and climate were used by EPM model in GIS environment (Refahi, 2007). The following sections describe the used techniques to generate the data layers and to evaluate the erosion factors for EPM model based on geographic information system.

\section{Data base generation}

Field-established, interpreted aerial photographs for both land-cover (1955s, 1965s and 1994s) and landforms were digitized in a standard digitizing tablet. Geometric correction was accomplished in the GIS through monoploting, a compensation approach for inner photo orientation that requires the metric coordinates of a set of at least nine control points from every photo and corresponding base map, and altitude form a digital elevation model (Solaimani, 2005). Thus, geometrically corrected mosaics of landcover and relief were obtained and labeled. Accuracy for both position and labeling was controlled thoroughly following Bocco and Riemann (1997). Geological data was extracted from interpreted aerial photographs at 1:50,000 scale, as well as filed observations (Fig. 2). Rock exposures in the study area consist of limestone, marl, shale, sandstone and conglomerate, with different erodibility. Lithological units were reclassified to 10 categories based on their sensitivity to erosion. Soil types were classified and assigned according to experimental data from field observation and sampling, using the approximate seventh soil taxonomy (Solaimani and Ahmadi, 2005). Data for estimating the coefficient of rock and soil resistance to erosion ( $\mathrm{y}$ - factor) were obtained by examining rock and soils from 300 test sites, representative of the major rock and soil map units. The test sites were subjectively examined and evaluated based on the type of lithology, thickness of beds, degree of cementation and density of fractures and joints. The coefficients of rock and 


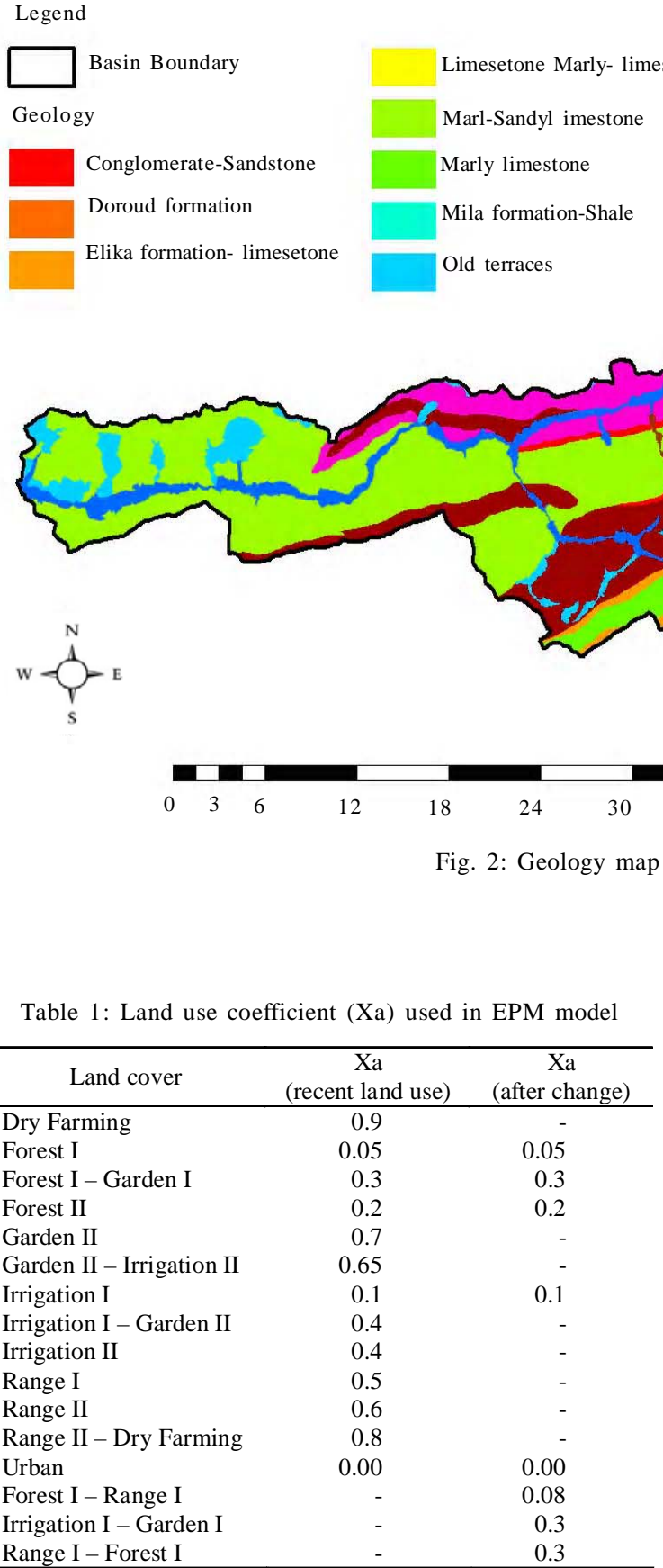

soil resistance to erosion ( $\mathrm{y}$ - factor) were assigned for each map class using the methodology thoroughly following Feyznia (1995). To determine the $X a$ - factor value utilized by the EPM method, land use map was generated using Indian remote sensing
Table 2: Using recent land use condition for prediction

\begin{tabular}{ll}
\hline \multicolumn{1}{c}{ Conditions } & \multicolumn{1}{c}{ Prediction } \\
\hline slope $=0-5$ and $\mathrm{Xa}>0.3$ & "Irrigation I - Garden I" \\
slope $=0-5$ and $\mathrm{Xa}<0.3$ & "Recent land use" \\
slope $=5-10$ "Forest I - Garden I" & "Forest I - Garden I" \\
slope $=10-15$ and $\mathrm{Xa}>0.3$ & "Range I - Forest I" \\
slope $=10-15$ and $\mathrm{Xa}<0.3$ & "Recent land use" \\
slope $=15-30$ and $\mathrm{Xa}>0.08$ & "Forest I - Range I" \\
slope $=15-30$ and $\mathrm{Xa}<0.08$ & "Recent land use" \\
slope $>30$ and $\mathrm{Xa}>0.2$ & "Forest I" \\
slope $>30$ and $\mathrm{Xa}<0.2$ & "Recent land use" \\
\hline
\end{tabular}

(IRS) data acquired in 2006 (Fig. 3). Several enhancements and classification techniques were used, related to ground truth data from field excursions in 2006 and 2007, to delineate training areas of identified land cover categories for the Southern Neka River Basin. Some ignorable land use changes were occurred between the time of satellite data collection and the field surveys. The land use coefficient (Xa) related to each land use class was estimated from EPM guide table (Refahi, 2007). This model classifies land uses in 10 categories and 


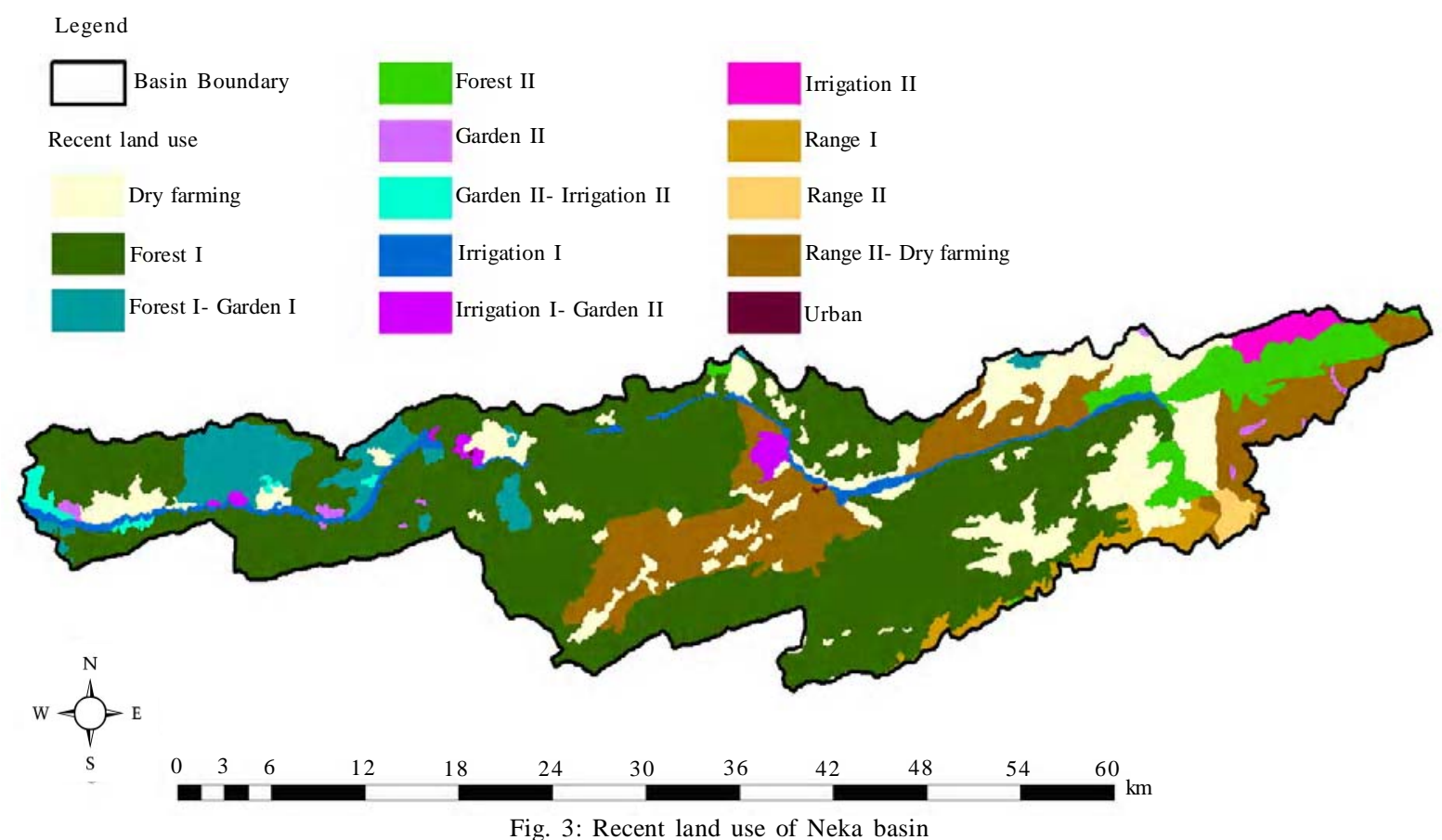

evaluates the coefficient Xa from 0.1 (for high-density woodland) to 1.0 (for badlands). The study area was classified to 16 categories and the land use coefficient was evaluated for each map class (Table 1).

Land slopes were calculated using 1:25000 topographic maps produced by the National Cartographic Center of Iran. Interpolation tool in Arc GIS9.2 software used the original digital data in micro station design (DGN) format to build up a digital elevation model (DEM) of the study area (Solaimani and Modallaldoust, 2008). A raster grid cell of $50 \times 50$ meters was generated and then applied for the DEM of the study area. The slopes were reclassified into five categories of $0-5,5-10,10-15,15-30$ and more than 30 . Therefore, estimated land use index was calculated for both the land and the amount of erosion. Finally, the mentioned method was used in Arc view/3.3 software to gain an optimized land use for the study area (Table 2).

\section{EPM Model}

The erosion potential method is a model for qualifying the erosion severity and estimating the total annual sediment yield of a catchment area. This model is initially developed in Yugoslavia by Gavrilovic (1988). EPM considers six factors such as; surface geology and soils, topographic features, climate (including mean annual rainfall and mean annual temperature) and land use. From these factors; exposed rock and soil, topography and climate are limited in natural class, but land use effect is depended on the human activities. The erosion potential method calculates the coefficient of erosion and sediment yield (Z) of a catchment area using the following equation:

$$
Z=y^{*} X a *\left(\psi+I^{0.5}\right)
$$

Where, $y$, is the coefficient of rock and soil resistance, from 2.0 to $0.25 ; X a$, is the land use coefficient, from 1.0 to 0.05 ; $\Psi$, is the coefficient value for the observed erosion processes, from 1.0 to 0.1 , based on the severity of erosion. The factor $I$ is the average land slope in percentage (Solaimani, 2007). For sediment production, the following equation was used:

$W s p=T * H * \pi * Z^{1.5}$ 
K. Solaimani et al.

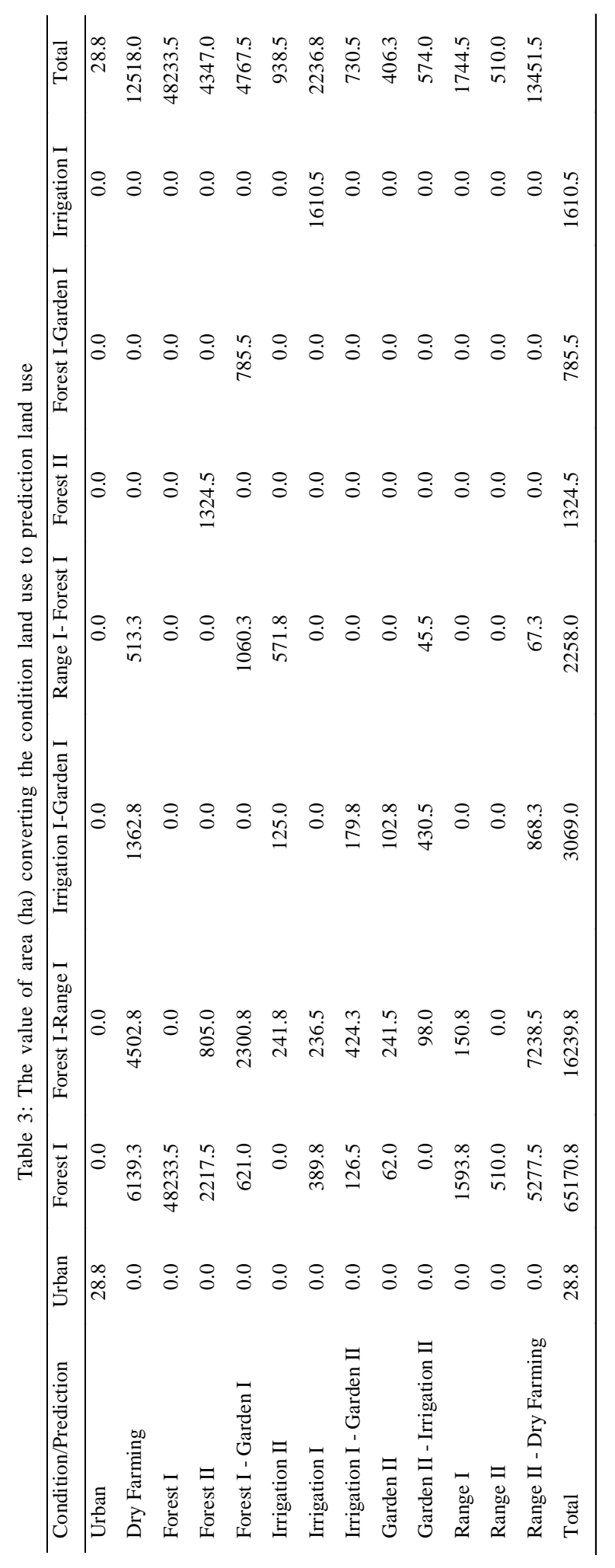




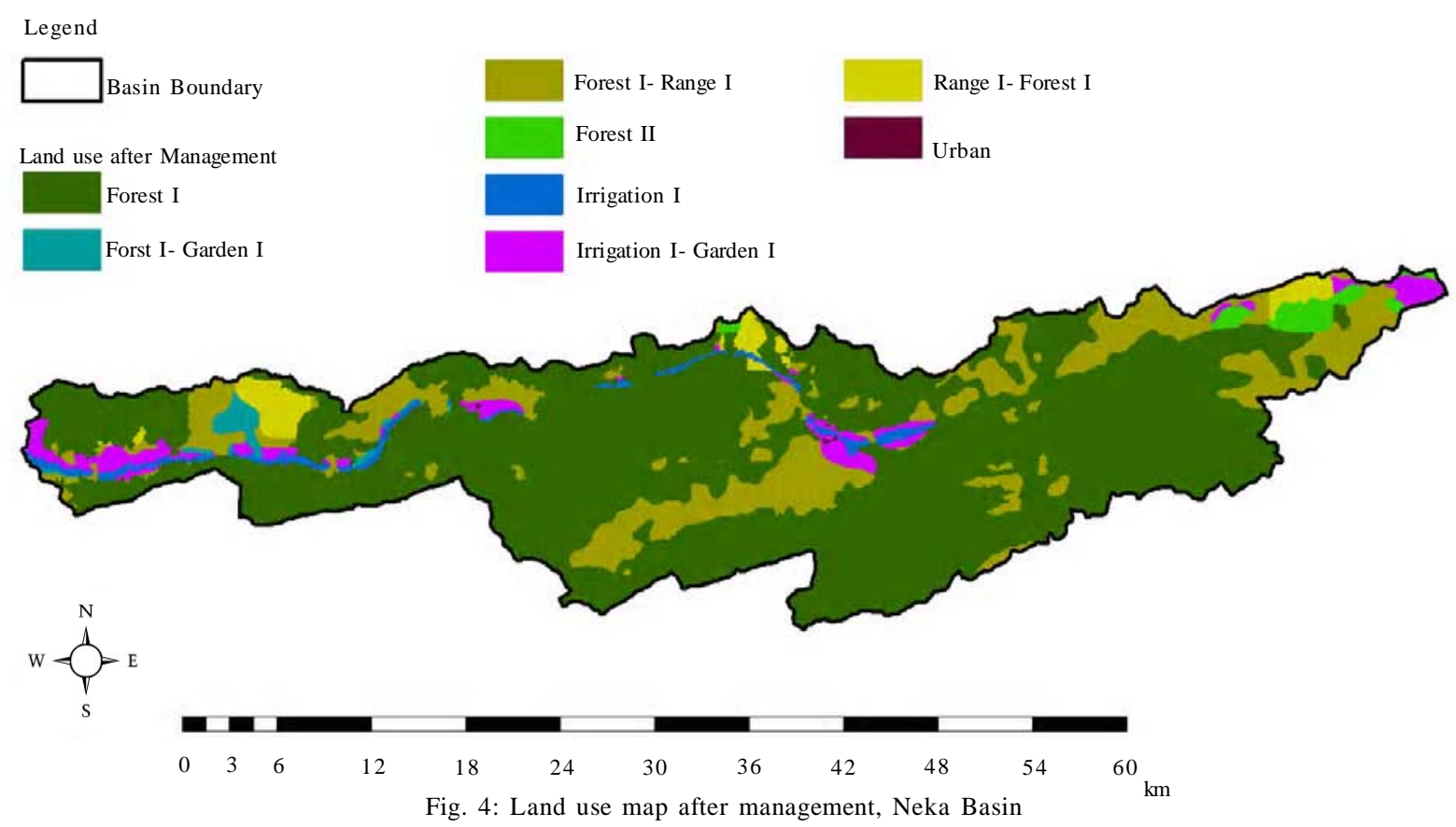

Table 4: Erosion conditions according to the recent land use, $\mathrm{m}^{3} / \mathrm{km}^{2} / \mathrm{y}$

\begin{tabular}{lrrr}
\hline \multicolumn{1}{c}{ Recent land use } & $\begin{array}{c}\text { Min. } \\
\text { erosion }\end{array}$ & $\begin{array}{c}\text { Max. } \\
\text { erosion }\end{array}$ & $\begin{array}{r}\text { Mean } \\
\text { erosion }\end{array}$ \\
\hline Dry farming & 78.4 & 61208.0 & 32253.6 \\
Forest I & 31.6 & 58182.9 & 464.7 \\
Forest I - Garden I & 137.4 & 41321.1 & 5983.0 \\
Forest II & 335.4 & 47871.1 & 2587.4 \\
Garden II & 252.5 & 35510.2 & 20086.9 \\
Garden II - Irrigation II & 137.4 & 25321.0 & 10891.1 \\
Irrigation I & 31.6 & 39097.1 & 795.8 \\
Irrigation I - Garden II & 2718.1 & 17961.0 & 10260.8 \\
Irrigation II & 1177.9 & 12236.9 & 4789.6 \\
Range I & 5893.5 & 19822.8 & 12216.6 \\
Range II & 7737.3 & 26057.7 & 17482.3 \\
Range II - Dry farming & 112.5 & 53695.1 & 26653.3 \\
Urban & 0.0 & 0.0 & 0.0 \\
\hline
\end{tabular}

Where, Wsp, is the average annual specific production of sediment per $\mathrm{m}^{3} / \mathrm{km}^{2} / \mathrm{y}, T$ is temperature coefficient, which is calculated as:

$$
T=(t / 10+0.1)^{0.5}
$$

Table 5: Erosion condition according to land use after land use/cover change

\begin{tabular}{lrrr}
\hline Predicted land use & $\begin{array}{c}\text { Min. } \\
\text { erosion }\end{array}$ & $\begin{array}{c}\text { Max. } \\
\text { erosion }\end{array}$ & $\begin{array}{c}\text { Mean } \\
\text { erosion }\end{array}$ \\
\hline Forest I & 31.6 & 6723.7 & 2630.4 \\
Forest I - Garden I & 137.5 & 4593.5 & 3095.8 \\
Forest I - Range I & 78.4 & 6723.7 & 824.1 \\
Forest II & 335.4 & 5983.9 & 1517.7 \\
Irrigation I & 100.7 & 1284.9 & 470.8 \\
Irrigation I - Garden I & 137.5 & 2718.1 & 2092.1 \\
Range I - Forest I & 948.7 & 6629.6 & 4912.0 \\
Urban & 0.0 & 0.0 & 0.0 \\
\hline
\end{tabular}

with $t=$ the mean annual temperature in degrees Celsius, $H=$ the mean annual amount of precipitation in $\mathrm{mm} / \mathrm{y}$, and $Z$ is the coefficient of erosion which was calculated from Eq. 1.

\section{RESULTS AND DISCUSSION}

The erosion potential method used after running in GIS software of Arc view/3.2 and the quantitative result of erosion severity (z parameter) mathematically 
was evaluated through Eq. 1 for values of factor classes. An area with $\mathrm{z}>1.0$ was identified with a potential of severe erosion, while areas with $\mathrm{z}<0.19$ correspond to a slight potential. The average annual specific production of sediments per $\mathrm{km}^{2}$ in $\mathrm{m}^{3} / \mathrm{y}$ (Wsp), was predicted using Eq. 2. The dominant erosion potential categories were slight to moderate. An accelerated and severe erosion potential category covers only $20 \%$ of the sub catchment area.

This part of the study area needs an urgent management of erosion hazard to reduce the rate of erodibility. About $70 \%$ of the areas with slope class of $0-5 \%$ were located in the low erosion potential category; however, more than $30 \%$ of the areas with slope classes of more than $30 \%$ show a rate of high to very high erosion potential. The results imply that after appropriate land use/cover change, the total erosion of basin has decreased equal to $89.24 \%$ (Tables 4 and 5). The amount of special erosion value for the study area was calculated about $144465.1 \mathrm{~m}^{3} /$ $\mathrm{km}^{2} / \mathrm{y}$. This amount of erosion would be decreased to $15542.9 \mathrm{~m}^{3} / \mathrm{km}^{2} / \mathrm{y}$ in the case of an appropriate management. This variation for the all basins is estimated equal to $128922.2 \mathrm{~m}^{3} / \mathrm{km}^{2} / \mathrm{y}$. It can be concluded that two major types of the changes were occurred with respect to the Figs. 3 and 4 and Table 3 such as dry farming to forest I (6139 ha), forest I range I (4502.8 ha) and range II - dry farming to forest I (5277.5 ha) and finally forest I - range I (7238.5 ha). The areas with dry farming have found in three major parts of upslope, middle and down slopes, as well as through the main channels of the watershed. These three types of the land uses are suitable for the agricultural activities (Makhdoum, 2007).

The land use conversion from dry farming to forest and range caused a considerable reduction of special erosion from 32253.6 to 2630.4 and 824.1 $\mathrm{m}^{3} / \mathrm{km}^{2} / \mathrm{y}$, respectively according to the filed investigation and extracted data from different sources. It can be observed that the areas with dry farming have located in margins of river on the low slope parts based on Fig. 3. The areas with an accelerated amount of erosion and sediment production have been identified as susceptible areas of erosion and sediment yield where needs a priority plan to soil conservation.
The areas with a low slope of the plain located on the banks of Neka River Basin contain have capabilities to farmlands. As indicated on Fig. 4 due to changing of the farming patterns, an extensive part of the study areas have transformed to irrigation farming, the forest and forest-range or forest-garden complex. Therefore, the erosion intensity decrease to 31.6 to $6629.6 \mathrm{~m}^{3} / \mathrm{km}^{2} / \mathrm{y}$ as these lands is located in suitable place. The area of rangelands and dry farming, which have measured about 28243.230 ha, $31.2 \%$ of the total area, decreases and reaches to range-forest and forest range complexes (18488.864 ha), $20.41 \%$. This reduction of the area and land use change leads to the exclusion of unsuitable and erosive lands. Finally, it can be concluded that the land use pattern of dry farming is insignificant and could be ignored with respect to the Tables and Figures.

Changing pattern of cultivation with an appropriate land management is a process that could be accomplished simply with new approaches and public participation for a better conservation of resources. As the results revealed, alteration and reformation of the land use would be efficient process in order to reducing the erosion rate (Fig. 4). There are many factors, which trigger land use changes patterns such as population growth, urbanization, production method and industrialization. The regional and national policies translate these driving forces into land use regulations, therefore, land use changes are often policy driven. Although, the biophysical conditions such as soil characteristics, climate, topography and vegetation determine mostly the spatial pattern of land use and its changes. The users and biophysical environment have the key role in creating land use changes. Finally, the importance of their behavior and decision policies in response to land use change has only been recognized (Veldkamp and Fresco, 1996).

\section{ACKNOWLEDGEMENTS}

Results on which the paper was based were developed during the interest research of the first author at the University of Agricultural and Natural Resources, Sari-Iran. The authors are grateful to the GIS and RS Centre of the Faculty of Natural Resource of Sari for technical supports during data capture and processing. 


\section{REFERENCES}

Aaviksoo, K., (1995). Simulating vegetation dynamics and land-use in a mire landscape using a Markov model. Landscape Urban Plan., 31, 129-142 (14 pages).

Arc View, (2002). Arc View User's Manual. ESRI, U.S.A.

Bakker, M. M.; Govers, G.; Kosmas, C.; Vanacker, V.; Van Oost, K.; Rounsevell, M. D. A., (2005). Soil erosion as a driver of land use change. Agri. Ecosys. Environ., 105, 467-481 (15 pages).

Ballantyne, C. K.; Witting tone, G., (1999). Late Holocene flood plain incision and alluvial fan formation in the central Grampian High lands, Scotland: chronology, environment and implications. J. Quater. Sci., 14 (7), 651671 (21 pages).

Bickik, I.; Jelecek, L.; Stepanek, V., (2001). Land use changes and their social driving forces in Czechia in the $19^{\text {th. }}$ and $20^{\text {th }}$ centuries. Land Use Pol., 18 (1), 65-73 (9 pages).

Bini, C.; Gemignani, S.; Zilocchi, L., (2006). Effect of different land use on soil erosion in the pre- alpine fringe (North-East Italy): Ion budget and sediment yield. Sci. Total Environ., 369 (1-3), 433-446 (14 pages).

Bocco, G.; Riemann, H., (1997). Quality assessment of polygon labeling. Photogramm. Eng. Remote Sens., 63 (4), 393-395 (3 pages)

Bodnar, F.; Spaan, W.; Hulshof, J., (2006). Ex- Post evaluation of erosion control measures in Southern Mali. J. Soil Tillage Res. 95 (1-2), 27-37 (11 pages).

Emmanouloudis, D. A.; Christou, O. P.; Filippidis, E., (2003). Quantitative estimation of degradation in the Alikamon river basin using GIS. In: De Boer, D.; Froehlich, W.; Mizuyama, T.; Pietroniro, A. (Eds.). Erosion prediction in Ungauged Basins: Integrating methods and techniques, Vol. 279. IAHS Publication, 234-240.

Fanetti, D.; Vezzoli, L., (2007). Sediment input and evolution of lacustrine deltas: The Breggia and Greggio Rivers case study (Lake Como, Italy). Quaternary International, 173-174, 113-124 (12 pages).

Feyznia, S., (1995). Rocks strength against erosion factors in different climates of Iran. J. Natural Res. Iran, 47, 95116 (22 pages).

Gavrilovic, Z., (1988). The use of an empirical method (erosion potential method) for calculating sediment production and transportation in unstudied or torrential streams. International conference of river regime, 18-20 May, Wallingford, England, 411-422.

Globevnik, L.; Holjevik, D.; Petkovsek, G.; Rubinic, J., (2003). Applicability of the Gavrilovic method in erosion calculation using spatial data manipulation techniques. In: De Boer, D.; Froehlich, W.; Mizuyama, T.; Pietroniro, A. (Eds.). Erosion prediction in Ungauged Basins: Integrating methods and techniques, 279. IAHS Publication, 22-233.

Hansen, A. J.; De Fries, R.; Turner, W., (2004). Land use change and biodiversity: A synthesis of rates and consequences during the period of satellite imagery. In: Gutman, G., Justice, C. (Eds.), Land Change Science: Observing, Monitoring, and Understanding Trajectories of Change on the Earth's Surface. Springer-Verlag, New York, 277-299.
Jordan, G.; Van Rompaey, A.; Szilassi, P.; Csillag, G.; Mannaerts, C.; Woldai, T., (2005). Historical land use changes and their impact on sediment flexes in the Balaton basin (Hungary). Agri. Ecosys. Environ., 108 (2), 119-133 (15 pages).

Makhdoum, M. F., (2007). Fundamental of land use planning. University of Tehran Press, $7^{\text {th. }}$ Ed, 289. ISBN: 964-034025-1.

Modallaldoust, S., (2007). Estimation of sediment and erosion with use of MPSIAC and EPM models in GIS environment. M.Sc. Thesis, University of Mazandaran, 95.

Refahi, H., (2007). Water erosion and consevation. Tehran University Press, 671. ISBN: 964-03-3818-8.

Rey, F., (2003). Influence of vegetation distribution on sediment yield in forested gullies. Catena, 50 (2-4), 549562 (14 pages).

Simonet, A. V. W.; Gautheir, E.; Barral, P.; Putit, C.; Buatier, M.; Daubigney, A., (2003). Land use change, soil erosion and alluvial dynamic in the lower Doubs Valley over the 1st millennium AD (Neublans, Jura, France). J. Archeol. Sci., 30, 1283-1299 (17 pages).

Solaimani, K., (2005). Interpretation methodologies in integrating aerial photography and digital base maps. M.Sc. students note, University of Mazandaran.

Solaimani, K., (2007). Principles of engineering watershed management. Mazandaran University, Note for M.Sc students, 112

Solaimani, K; Ahmadi, M., (2005). Rivers, University of Mazandaran Press, 578.

Solaimani, K.; Modallaldoust, S., (2008). Production of optimized DEM using IDW interpolation method. J. Appl. Sci., 8 (1), 104-111 (8 pages).

Stoate, C.; Boatman, N. D.; Borralho, R. J.; Carvalho, C. R.; De Snoo, G. R.; Eden, P., (2001). Ecological impacts of arable intensification in Europe. J. Environ. Manage., 63, 337-365 (29 pages).

Sun, B.; Zhou, S.; Zhao, Q., (2003). Evaluation of spatial and temporal changes of soil quality based on geostatistical analysis in the hill region of subtropical China. Geoderma, 115 (1-2), 85-99 (15 pages).

Szilassi, P.; Jordan, G.; Van Rompaey, A.; Csillag, G., (2006). Impacts of historical land use changes on erosion and agricultural soil properties in the Kali Basin at Lake Balaton, Hungary. Catena, 68 (2-3), 96-108 (13 pages).

Van Rompaey, A. J. J.; Govers, G.; Puttemans, C., (2002). Modeling land use changes and their impact on soil erosion and sediment supply to rivers. Earth Surf. Proc. Land., 27 (5), 481-494 (14 pages).

Van Rompaey, A. J. J.; Govers, G.; Van Hecke, E.; Jacobs, K., (2001). The impacts of land use policy on the soil erosion risk: A case study in central Belgium. Agr. Ecosys. Environ., 83 (1-2), 83-94 (12 pages).

Vanniere, B.; Bossuet, G.; Simonet, A.V. W.; Gautheir, E.; Barral, P.; Putit, C.; Buatier, M.; Daubigney, A., (2003). Land use change, soil erosion and alluvial dynamic in the lower Doubs Valley over the 1st millennium AD (Neublans, Jura, France). J. Archeol. Sci., 30, 1283-1299 (17 pages). 
Veldkamp, A.; Fresco, L. O., (1996). CLUE: A conceptual model to study the conversion of land use and its effects. Ecol. Model, 85 (2-3), 253-270 (18 pages).
Verstappen, H. T.; van Zuidam, R. A., (1991). The ITC System of Geomorphological Mapping. ITC Publication, 10 Enschede, The Netherlands.

\section{AUTHOR (S) BIOSKETCHES}

Solaimani, K., Ph.D., Associate professor, Department of Watershed Management, University of Agriculture and Natural Resources, PoBox 737, Sari, Iran. Email: solaimani2001@yahoo.co.uk

Modallaldoust, S., M.Sc. student, Department of Watershed Management, University of Agriculture and Natural Resources, Sari, Iran. Email: saeed2007_1980@yahoo.com

Lotfi, S., Ph.D., Assistant professor, Department of Geography, University of Mazandaran, PoBox 416 Babolsar, Iran. Email: sedlotfi@yahoo.com

This article should be referenced as follows:

Solaimani, K.; Modallaldoust, S.; Lotfi, S., (2009). Investigation of land use changes on soil erosion process using geographical information system. Int. J. Environ. Sci. Tech., 6 (3), 415-424. 